\title{
A Discursive Examination of White Americans' Attitudes about White-Black Interracial Marriages in USA
}

\section{Ilham Malki}

\section{Abstract}

The primary objective of this article is to manifest by means of discourse analysis the attitudes of White Americans towards White-Black interracial marriages. The research draws on qualitative analysis of the discourse of some white Americans to find out the genuine convictions they bear about interracial unions, especially those incorporating Blacks and Whites. Regardless of the fact that White Americans have asserted their approval of White-Black marriages, the results of the study reveal that some WhiteAmericans are still not in favour of their close relatives marrying outside their own race. As Van Dijk (1992) postulates, one of the distinctive peculiarities of contemporary racism discourse is its denial. On accounts of rigid constraints posed upon overt expression of racist perspectives, individuals bring about a set of discursive strategies that enable the deliverance of negative constructs without being trapped by racism charges. In addition to the denial of racism, the results of the research disclose various strategic choices through which white Americans legitimize their views towards white-black interracial marriages. Such choices embark on justifications, denying, excuses, positive self-presentation, negative other-presentation, and blaming the victim. (Van Dijk: 1992)

Keywords: White-Black interracial marriage, racism, denial, discourse analysis

\section{1-Introduction}

The United States of America is one of the most ethnically and racially diverse countries all over the world; it "is a nation of nations, made up of people from every land, of every race and practicing every faith." (Powell, 2001, web) America owes its culturally diverse picture to the large-scale migration of people from various ethnically and racially different countries throughout its history as well as to the heritage of the Native Americans. The diverse picture that distinguishes the social 
make-up of the American society is reflected in the heterogeneous kinds of relationships that join the various individual entities of America. One of these relationships that celebrates the different racial and ethnic differences of the American nation is interracial marriage. The latter is, by definition, a phenomenon that results from the involvement of two people of different races/ethnicities who willingly opt for beginning a relationship together. In America, the interracial marriage is said to increase at a relatively rapid pace due to "the decrease in white prejudice against Blacks, and the narrowing of the racial gap in education, income, and occupation." (Honeycutt, et al: 2005)

\section{2-Background of the study}

It is worth saying that interracial marriage in America touches the different races that compose the social structure of the American society, namely the Native Americans, African Americans, Asian, and White (European) Americans. However, this paper sheds light on white and black interracial marriage. A study has been carried out by the Pew Research Center reveals that "of the 275,500 new interracial marriages in 2010, 14.9\% were White-Black." ${ }^{2}$ Tough this number is not highly significant compared to other forms of interracial marriages, more specifically White-Hispanics 43\% and White-Asian 14,4\%, but "it is undeniably increasing rapidly" (Qian:2014) since 1980 in which the figure did not exceed $5 \%$

${ }^{2}$ Staff TNO, "Interracial Marriages in the US: Facts and Figures (and Why White People Must Have More Babies) " http://newobserveronline.com/interracial-marriages-inthe-us-(accessed 10 January. 2014)

The main objective of this paper is to examine white Americans attitudes towards White-Black interracial marriages in USA and highlight the different discursive strategies through which they justify these attitudes. In addition, this study aims at highlighting how the whites' discourse with respect to White-Black interracial marriages serve the ideologies of the dominant group. Before delving deeply into the primary topic a historical background of interracial marriage is provided along with examining some approaches that outline the motives behind integrating in such kind of relationships.

\section{3-Historical Background of Interracial Marriages in America}

Indeed, the White-Black union has historically been the most controversial issue in the history of America's interracial marriages since the $15^{\text {th }}$ century. In 1660's, several American states, markedly, Maryland, Massachusetts, Pennsylvania, North Carolina, 
and South Carolina enacted a number of anti-miscegenation laws which totally outlawed interracial marriages as it

was leading to " abominable mixture and spurious issue," (Johnson, 2003, pp:23) which eventually would stain the 'white gene pool.' The abolition of slavery in 1865 did not side away the legal restrictions over interracial marriages in America; conversely, it strived to widen the gap between the White and the so-called 'inferior' Black race through the legislation of "Black Codes" that enhanced the official interdiction of the marital combinations between the White and African Americans. However, the anti-miscegenation laws did not hamper the White race from taking advantage of Black women with whom they gave birth to many children. The antimiscegenation laws maintained the prohibition of interracial marriages in 16 states, more specifically, in the South and the Midwest, until 1958. The cancellation of the anti-Jeter, a black woman, who went to Washington, D.C., a state which did not prohibit interracial unions, to get married. When Mildred Jeter and Richard Loving returned to their Virginia home, they were arrested and indicted for breaking Virginia's anti-miscegenation laws. Miscegenation laws, then, burst with the story of the interracial couple, Richard and Mildred Loving.

During the trial, the judge who sentenced the Lovings to one year in prison, reverberated the Johann Friedrich Blumenbach's 18th-century interpretation of race, "Almighty God created the races white, black, yellow, Malay and red, and he placed them on separate continents. And but for the interference with his arrangement there would be no cause for such marriages? The fact that he separated the races shows that he did not intend for the races to mix." (Sollors , 2000, pp.7) For nine years, The Lovings waged a campaign against the anti-miscegenation laws through the Supreme Court that eventually revoked the Lovings' accusations in 1967. The court's decision confirms "the freedom to marry, or not marry, a person of another race resides with the individual and cannot be infringed by the State;" (Botham, 2009, pp. 175) and hence the anti-miscegenation legislation was officially declared invalid.

\section{3-1-Approaches to Interracial Marriages}

According to Paul Taylor, the Pew Research official "Intermarriage in this country has evolved from being illegal to being a taboo to being merely unusual....with each passing year, it becomes less unusual." (Jordan: 2014, web) In the light of the increasing rate of interracial marriages in America, a number of theories have been developed with the objective of determining the primary factors that motivate the 
White and Black race to get involved in such kind of marital relationship, namely, the Structural Theory, the Status Exchange Theory, and the Racial Motivation Theory.

Initially, the Kouri and Lasswell's Structural Theory (1993) suggests that "interracial couples marry for the same reasons that racially homogeneous couples do: they meet, they discover similar interests, they fall in love, and they decide to marry." (Ross, 2004, pp. 3) In the same manner, the Structural Theory affirms that interracial marriage is more common in a setting where different races get the opportunity to be engaged in any form of social contact, be it at workplace, neighbourhoods, or universities. Unprecedented interest given to White-Black interracial marriages in media and academic research; in addition to the close social contact among the different ethnic and racial groups have raised the public acceptance of mixed-race relationships.

In contrast with the Structural Theory, the Racial Motivation Theory (Kouri and Lasswell 1993) proposes purely racial incentives for the couple who interracially marry. The basic tenet of the Racial Motivation Theory is based on the idea that the couple is attracted by the exotic cultural differences of each other. It is the curiosity about those who belong to a heterogeneous cultural pool that heightens individuals' desire to be engaged in interracial relations. (Orbe and Harris, 2008)

The Status Exchange Theory (Merton 1941), by contrast, is based on the fact that in Black-White marriage, which most often joins between high status black men and low status white women, the objective is to exchange the so-called "higher status" of the female partner as a white for her male partner's higher socio-economic status. In this sense, the interracial marriage as a social behavior is the result of an exchange process through which each individual seeks the satisfaction of a particular psychological or economic need.

However, this approach has been the target of many critical studies for lacking enough empirical support. (Wang: 2006) Regardless of the fact that the aforementioned theories suggest some possible motivating factors that urge the white and the black race to get engaged in interracial marriage, yet no theory could be exclusively used to provide the very real factors for which Whites and Blacks are involved in interracial marriages.

\section{3-2- Public Attitudes Towards Interracial Matrimony}

Since interracial marriage falls within the realm of race issues, it is highly recommended to heed the public attitudes towards interracial marital unions. These 
attitudes are meant to measure Americans' insights of race relations as well as the quality of these relations in the contemporary America. For the sake of assessing Americans' attitudes towards White-black interracial marriages, Gallup's Minority Rights and Relations poll, conducted a survey (June 13-July 5, 2013) which targeted 4,373 Americans, including 1,010 non-Hispanic blacks.

\section{Approval of Black-White Marriage Among Whites and Blacks}

\section{Selected trend}

Whites ${ }^{\wedge}$ Non-Hispanic blacks

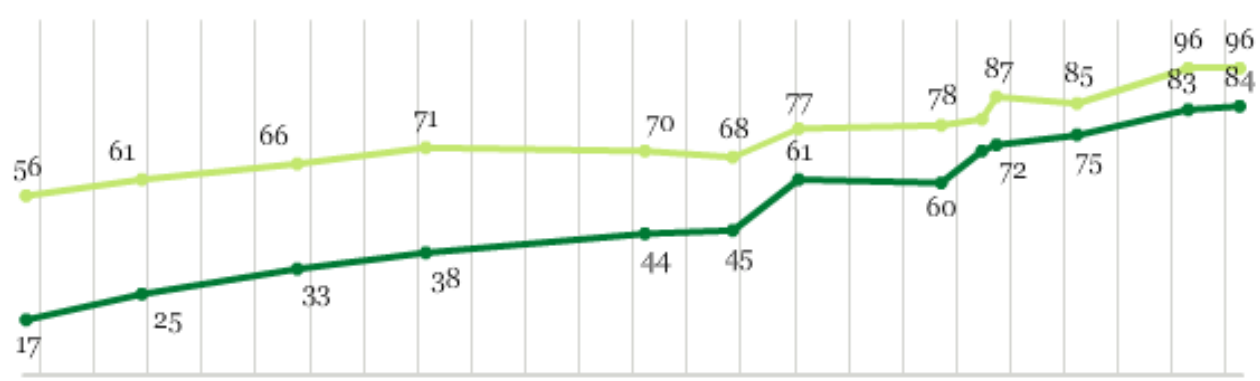

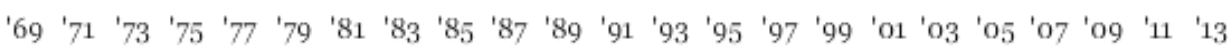

1958 wording: "... marriages between white and colored people"

1968-1978 wording: "... marriages between whites and nonwhites"

^Trend from 1968-2003 includes Hispanics; trend from 2004-2013 is for non-Hispanic whites only

\section{GALLUP'}

(Adapted from: Gallup poll: 2013)

The survey results reveal that Blacks' approval of White-Black marriage (96\%) is now nearly universal, while Whites' approval is 12 percentage points lower, at $84 \%$. Americans' attitudes towards interracial marriage have undergone dramatic changes since the 1950s when disapproval was well over $90 \%$, to the point today when approval is approaching 90\%. (Gallup Poll) The significant shift in the American public attitudes towards this kind of mixed-race relations reveal to what extent the American society's perception of race issues have substantially changed.

Notwithstanding the fact that the majority of the White Americans approve WhiteBlack marriage, yet in reality the latter remains rare as they represent, according to the Census poll, "less than 1\%." The low rate of White-Black interracial marriage underlines that this kind of relationship is still unfavourable for White Americans. It seems, then, race issues are still prevailing in the American society. In this regard, 
Field, et al (2013) argue that "despite these changes, Black/White marriage still strikes a raw nerve in U.S. society; the colour line remains strong."(742) Before tackling the issue of white Americans' attitudes towards white-black interracial marriages, it is significant to define racism.

\section{3-3-What is Racism}

Gosfoguel (2016: 10) identifies racism as "a global hierarchy of superiority and inferiority along the line of the human that have been politically, culturally and economically produced and reproduced for centuries by the institutions of capitalist/patriarchal western centric/Christian-centric modern/colonial world system." The above definition distinguishes between two ranges of individuals. Those who establish themselves on the top of the line of the human and those who are at the top of the line of the human. The former are identified within social boundaries as human beings, and henceforth, are entitled human rights, social recognition, and material privileges. As for the second range of individuals, who are beneath the line of the human, they are recognized as 'non-human, and therefore, they are denied "the extension of rights, material resources and the recognition of their subjectivities, identities, spiritualties and epistemologies." (Gosfoguel, 2016, pp. 10)

It is worth mentioning that racism is recognizably different from racial inequality and racial discrimination. While racial inequality is typically related to asymmetric distribution of power, economic resources and social opportunities, racial discrimination highlights any discriminatory practices against people on the basis of their race. However, racism as a social practice is frequently embedded in both racial inequality and racial discrimination. Still, one cannot anticipate racial inequality and racial discrimination as inevitable outcomes of racism.

Racism does not only cover the set of beliefs an individual or ethnic group firmly holds to justify their discriminatory behaviours against others, it covers a stored system of cognitive stances that distinguishes 'the self' from 'the other' also. It is in this manner that racism affects the way in which people conduct themselves relative to their social norms.

Research within the field of racism identifies three types of racism, "personal, institutional, and social." (Blum, 2002, pp. 9) Personal racism is the set of views that regards an individual or members of a social group as inferior to another individual or social group on accounts of physical differences. Institutional racism, on the other hand, manifests through inferiorizing laws and legal practices enacted by social 
institution, such as universities, hospitals, etc., and that lead racial inequality. The third type of racism that Blum (2002) refers to is social racism or sociocultural racism. The latter incorporates "racist beliefs, attitudes, and stereotypes widely shared within a given population and expressed in cultural and social modes such as religion, popular entertainment, advertisements, and other media." (Blum, 2002, pp. 9)

\section{4-Research Question}

Notwithstanding the considerable increase in White-Black matrimonial relationships in America, the disapproval of these relationships has not necessarily decreased. The desire of two individuals belonging to different races to join in matrimony cannot negatively alter the social construction of race in any country. Yet, the society's reactions towards interracial marriages, be they behavioural, discoursal, or visual, provide deep insights into the social hierarchy of race. The aim of this paper, therefore, is to unravel the attitudes of White Americans towards White-Black marriages. It also examines the discursive mechanisms through which they justify their attitudinal stances towards White-Black interracial marriages. In sum, the study answers the following questions:

What are the attitudes of White Americans towards White-Black interracial union?

What are the discoursal patterns through which White Americans justify their attitudes towards White-Black couples who enter into marriage?

What social purposes, the White Americans' prejudice discourse towards White-Black matrimony function?

\section{5-Research Methodology and Data}

The current study employs discourse analysis as a qualitative framework to examine the selected data. It, more specifically, applies Van Dijk's (1984) (1992)'s analytical theories to examine the discourses White Americans produce about White-Black interracial marriages. Considerable research studies have been conducted within the field of discourse and racism to provide deep insights into the correlation between discourse and contemporary forms of racism. When critically approached, discourse should not be regarded as merely a structural construct, text and talk; rather, it should be examined as a social process that contributes to the production and reproduction of racism. In this regard, Wodak and Reisigl (1999) postulate that "racism, as a social construct, as a social practice, and as ideology, manifests itself discursively. On the one hand, racist opinions and beliefs are produced and reproduced by means of 
discourse, and through discourse, discriminatory exclusionary practices are prepared, promulgated, and legitimated." (pp: 175-176)

In order to understand how is the production and reproduction of racism established through discourse, Van Dijk (1993) argues that the analysis of discourse should be carried out across the micro and macro levels of racism as well as across the social practices, mental models, and ideologies people construe about either social members or certain situations. Based on his triangle socio-cognitive model, Van Dijk (1984) adapts a social, cognitive, and discursive analysis of the production and reproduction of racism. To illustrate the relevance of this model to the understanding of racism discourse, Van Dijk (2015) explains:

the discursive component of the theory deals with the many structures of racist text and talk, such as specific topics, negative descriptions of minorities or immigrants, disclaimers, the lexicon and other grammatical structures, topoi, argumentation or metaphors, among many other structures of ideological polarization between 'Us' and 'Them'. Secondly, such discourse structures are interpreted and explained in terms of underlying, socially shared ethnic prejudices and racist ideologies and the ways they influence the mental models of individual language users. Thirdly, such discourses and their underlying cognitions are socially and politically functional in the (re)production of ethnic domination and inequality by white dominant groups against minority groups or immigrants. They are controlled by powerful symbolic elites and organizations, e.g. those of politics, mass media and education, who have privileged access to public discourse. Each of these components of the theory and the analysis is necessary to account for racist discourse in society. We shall show below that a similar triangular approach is necessary for the study of racism and anti-racism. (64)

While examining the role of discourse in production and reproduction of racism, Van Dijk (1992) emphasizes that contemporary race discourse is distinctively identified with the denial of racism. Societal norms against perspicuous stances of racism against minority groups has fostered the inauguration of discourse that considers negative attributes about 'the other' as non-racist and justifiable. Henceforth, negative representations and judgement moves about 'the other' are typically prefaced by the use of disclaimers, justification, excuses, or reversal that simultaneously serve positive self-presentation purposes.

By means of socio-cognitive approach of Van Dijk (1984) (1992), the researcher examines the discourse of White Americans to identify their attitudes towards White- 
Black interracial marriage. Furthermore, the study aims at investigating the discursive mechanisms through which White Americans legitimize their attitudes about White-Black interracial unions. When people produce discourse about a particular minority group, they do not only deliver verbal utterances, but they discursively manifest their cognitive structures, shared knowledge, and ideologies as a social group as well. It is significant to indicate that a comprehensive critical study of racism discourse requires probing the social dimension under which covert ideologies occur. In other words, the socio-cognitive approach underlines the different cognitive structures that correlate with discourse at its all levels and the different possible means that both maintain power, social injustice and establish ideologies.

The data of this study has been drawn from the discourse of White Americans who have been interviewed in two TV talk shows, Jenny Jones talk show, and Trisha Goddard talk show, and a CNN news program. Accompanied by their relatives having a black spouse, the participants have been interviewed to identify their attitudes and beliefs about their close relatives marrying black partners. The third source of the data is extracted from the discourse of Keith Bardwell who represents Louisiana Justice of the Peace. The data has been drawn from YouTube processor. The analysis of the data is performed in the light of discourse analysis based on Van Dijk's sociocognitive approach (1984-1992)

\section{6-Data Analysis and Results}

\section{6-1- It is Not that Serious}

In October 2009, Keith Bardwell, a Robert, Louisiana, Justice of the Peace, refused to perform a marriage of Beth and Terence McKay based on the fact that they are interracial couple. The judge points out "I don't do interracial marriage." Having been interviewed by CNN (Nov 4, 2009) about the basis on which he refused to perform interracial marriages, Bardwell explains that "I came to the conclusion that most Black society does not readily accept offspring of such relationships, and neither does White society." He continues, "I don't want to put children in a situation they didn't bring on themselves. In my heart, I feel the children will later suffer."

Judge Bardwell strongly believes that interracial marriages pose a number of challenges not only on the couple but also on the offspring of this kind of communion. He later explained that the decision was taken only on the ground of his concern for the serious problems biracial children would experience, "I do ceremonies for black 
couples right here in my house; my main concern is for the children." In this respect, Bardwell asserted that biracial children are likely to face rejection from most of black and white society as well.

Interestingly, the very early utterance judge Bardwell produces in another CNN news show (Oct 19, 2009) as a response to the TV presenter's question: "do we have the news straight that you refused to grant the marriage license based on the fact that they are an interracial couple?" displays that he is aware of the pertinence of the situation he has involved himself in; and thus, he is much more focused on saving his individual face. He initiates his speech with an evasive discourse strategy encoded in denial of responsibility through which he states, "one thing is the Justice of Peace does not issue a marriage license permit. Nobody, no Justice of the Peace does. We only, we only perform the ceremony." The production of the previous move serves as a mitigating strategy that reduces the bad effects of his racist act against the couple and makes it seem less important. Remarkably, Bardwell's pronominal choice of "exclusive we" serves to downplay his involvement in this controversial situation by anchoring himself as a judge member in the Justice of Peace while the TV presenter's question is directed to him. Bardwell does not provide his answer with the first subject pronoun "I"; instead, he uses the exclusive "we" to deflect responsibility and distance himself from the controversial event, hence, diminishing the threat to his individual face when disconcerted with a face-threatening question. Bardwell's intention of attenuating the situation is manifested once more with the discourse marker 'only' that performs depreciatory function.

A further instance of Bardwell's intention of depreciating the situation and saving his face is corroborated as he responds to the TV presenter's statement: "but, you refused to perform the ceremony. The judge produces a second pair part to the presenter's first-pair part in the form of repair utterance, "I recuse myself of performing the ceremony." Noticeably, Bardwell does not provide a direct answer to the presenter's question. Instead, he resorts to euphemism as an evasive discourse strategy that serves face-keeping purposes. To legitimize his behaviour against the couple, Bardwell refers to judicial recusal as a legal right granted to any judge who wants to abstain from participating in an official action: "a judge can legally recuse himself eh, here or uh, of a case or marrying people."

\section{6-2-I Am Not Racist! It is About the Offspring}

Bardwell's refusal to perform the marriage ceremony for Beth and Terence McKay reveals his personal attitudes that disapprove interracial marriages between White 
and Black Americans. As has been asked by the presenter on which basis he recuses himself of marrying the couple, the judge argues "well! you said a while ago the reason uh that are, that are, (pause) there, uh because, the, they (pause) of, had, (sigh) on account of number of people that was born on in a situation and they claim that blacks or the whites didn't accept the children and I don't want to put the children in that uh uh, in that position." Having examined Bardwell's response, the researcher underlines very interesting discursive aspects of his speech, namely hesitation and inability of articulation that turn up when interrogated about his incentive of refusing to perform the ceremony. From the beginning of his intervention, Bardwell has been confident in his discourse and thoughts, and verbalized his statements without hesitation. However, once the conversation touches upon the reason why he has refused to perform a matrimony for the interracial couple, Bardwell becomes hesitant, unable to utter complete and meaningful utterances, and makes pauses and sighs before he finally succeeds in formulating his statement.

The excuse move the judge uses for not doing the interracial wedding, namely the mixed-race children's rejection by society, grants his racism a kind of a pretty polished and a happy face that would justify his bigot perceptions against interracial marriage. Strikingly is the fact that throughout his carrier of 34 years as Louisiana justice, Bardwell refused to perform any kind of interracial marriage. By so doing, Bardwell gives supremacy to his convictions over his commitment to the law that accords any American individual the freedom to marry or not marry outside of his/ her race.

Bardwell's discourse about interracial marriage is loaded with his concern about the negative outcome of White and Black interracial marriage, more specifically, social rejection of biracial children. As a discursive construct, social rejection is cognitively interpreted as a distressing situation that highlights further underlying concepts such as estrangement from family and society, anxiety, embarrassment, juvenile delinquency, etc. Bardwell's reference to 'rejection' in his discourse, "Blacks or the Whites didn't accept the children," cognitively emphasizes the fear of social exclusion, bullying, hostility, and accordingly the fear of criminal behaviours and other painful situations that replete Bardwell's mental model, and therefore, control his discourse.

Ultimately, the use of such construct and its cognitive outcome on interlocutors is not socially innocent. If the rejection of biracial children successfully urges emotional responses such as fear of the likely negative outcomes social rejection may cause, and some of these have been listed above, this may develop anti- White and Black 
interracial marriage attitude, e.g., by generalizing mental models of other negative consequences that may generate of socially rejecting biracial children.

\section{6-3- Blacks Are Not Pretty Sight}

A white American mother, Casey, has not remised to express disgust towards her two daughters, namely Cashley and Cynthia, simply because they have engaged in interracial relationship. Having been hosted by Trisha Goddard show, Casey expresses her view that she is not happy with the choices her daughters have made with regard to their engagement to black males. When Casey has been interrogated about what that brings up in her mind once she sees a black male, she answers, "It's just not pretty sight." She continues, "I want them [daughters] to be with sexy, hot, white, professional guys." Casey's utterances reflect the cognitive content she stores about black people: blacks are not pretty sight, blacks are not sexy, blacks are not hot, blacks are not professional, and blacks are not white. Casey's discourse is a concretized representation of her beliefs and opinion about black ethnic group. The production of such beliefs do not serve information-processing; rather they provide evaluative belief framework " that "is needed to assess the (inter)subjective "position" of social members toward such episodes." (Van Dijk, 1987, pp.189)

\section{6-4- Positive Self-Presentation}

Lest she should be perceived as breaking the American societal norms of tolerance, Casey embarks on discursive mechanism that represents the self positively. During her interview with Trisha Goddard, Casey tries to speak her attitudes in such a manner that her audience construe a positive or at least neutral impression of her. Casey's positive self-presentations are articulated in the following phrases: "to me John and James are very nice guys. I have nothing bad to say about them. Uh Umm, They are just of a different culture." The white mother remains determined about avoiding the interlocutors' negative impression and evaluation about her personality that she keeps reminding her daughters and the TV presenter, Trisha, that "it's not the colour I'm talking about, it is the culture."

When Casey asserts that she has nothing bad to say about her daughters' black partners and that her dissatisfaction is not established on colour basis, she leads the audience to focus more on a permanent attitude, rather than on the specific attitudinal stance she is currently verbalizing (cultural differences.) By so doing, Casey is implicitly interrupting any inference process the interlocutor may make from her particular attitude (culture differences) to a more general impression about Blacks. It 
is in such a way that Casey tries to justify her specific negative attitude about her daughters having black partners.

\section{6-5- I Am Not Racist, I Was Taught to Stay Within My Race}

Having black sons-in-law is a disgusting fact for Casey. Her dissatisfaction stems from the fact that "I was just raised in a small town and I was taught to stay within your own race and just I never thought my daughters would do this." She continues that her daughters "will be judged throughout their lives." Things have become worst when Casey has had knowledge of her Cynthia's pregnancy; she states that the piece of news "made me totally sick to my stomach." Casey is mortified that there will now be black blood mixed in her family bloodline. She has found it difficult to accept having a biracial baby within her family; she says, "It's hard to accept the culture the baby coming into. I have a very large family and there's not one black person in my family." Casey's attitude against White and Black interracial marriage is not premised on culture differences as she is trying to prove; it is based on colour accounts, and this is clearly stated in the last part of her above statement: "there's not one black person in my family."

As Casey has expressed her concern about mixing her White family bloodline with Black bloodline, Trisha asks Casey if she is racist. Casey immediately denies racism: "no, no, no, I'm not." However, what she provides as a justification of her non-racism does in fact emphasize her racist ideology against blacks: " no, I mean, I just don't want my daughters been and it's not just blacks. I don't want them with Jamaicans." Casey's utterance once again highlights the issue of colour as a foundation of her attitudes against White and Black interracial marriage.

Throughout the show, Casey openly admits that she will never accept the interracial relations her daughters have engaged in. Her personal attitudes are overloaded with racism not only against her daughters' partners but also against her biracial grandchild that she acknowledges she will not be there for his birth. For fear that she should be perceived as a racist, Casey draws on excuses as a discursive strategy of racism denial. She states that her convictions have been strongly shaped by that of her family: "I was just raised in a small town and I was taught to stay within your own race." Additionally, the very truth that her large family lacks a history of interracial marriages has made her reluctant to accept it within her small family. Interestingly, the white mother makes use of her family's influence on her as a form of racism denials and as a means to justify her thorough disapproval to her daughters' interracial relations which she states that it is based on her concern for her daughters 
not to be judged by society. However, Casey's discourse highly dispatches racist views and prejudice about Black race.

\section{6-6-Negative Other-Presentation}

\section{6-6-1- Blacks Cannot Be Trusted}

Some white Americans show no concern about unequivocal expression of their negative attitudes against White and Black interracial marriages. Their racist perspective draws from the conviction that hierarchies exist among humans at individual, institutional and cultural levels. There is, henceforth, a polarisation classification between the superior 'self' and the inferior 'other' through processing negative portrayal of the other.

Billy, a white American, is upset that his sister is dating a black man. During his interview with Jenny Jones (2014), Billy threatens "if my sister marries this black man, she will never be invited to my house again." Billy expresses his categorical objection to have a black brother-in-law. For face concerns, he supports his objection with presenting Blacks negatively. In this regard, he points out "black people can't be trusted. Every time you try, they just betray you." He continues, "every time you try to trust black men, they're going to stab you back, that's from my experience." Based on his personal experience with some Black Americans, Billy formulates strong interpretations of generally negative truth about Black people. Seemingly, Billy has had some negative experiences with some Blacks who have been untrustworthy and betraying. As a cognitive reaction, Billy constructs a personal mental model that portrays the Black race as untrustworthy and betraying. By justifying why he holds negative attitude about his sister marrying a Black person, Billy implicitly urges his recipients not to blame his attitudes that raise from Blacks misdeeds. He, thus, presents himself free of racism and even claims being a victim of "reverse racism" (Jensen, 2005) Blacks practise against the White dominant group. Therefore, the overgeneralization moves and negative stereotypical utterances Billy produces against black people may be regarded as integrally connected to the justification force of his racist ideology.

\section{6-6-2- Interracial Couples De-Promote Whites' Greater Unity}

In November 2011, Stella Harville and her fiancé, Ticha Chikuni, a native of Zimbabwe who sung once in Kentucky church, were banned from a Kentucky church for being an interracial couple. (Hallowell, 2011) The church also made it clear, via a resolution, that married interracial couples are prohibited from becoming members of the 
church. WYMT, CBS-affiliated television station, obtained a copy of the resolution. It states:

That Gulnare Freewill Baptist Church does not condone interracial marriage. Parties of such marriages will not be received as members, nor will they be used in worship services and other church functions, with the exception being funerals. All are welcome to our public worship services. This recommendation is not intended to judge the salvation of anyone, but is intended to promote greater unity among the church body and the community we serve. (Hallowell: 2011, web)

The resolution was made when "members of the congregation had said they would walk out if Chikuni sang again." (Hallowell: 2011, web) The church makes an open acknowledgment that interracial couples can neither perform interracial marriages nor be members of the church. Additionally, those who are interracially married or engaged are not allowed to take part in worship services but they may attend them.

The decision of banning interracial couples from the church has been taken by virtue of personal attitudes the church body holds against this kind of relations. The church reaction reveals a large amount of overt racism and prejudice against Black race that is perceived as a threatening force to the unity of the White community. This incident outlines that the relationship between Blacks and Whites in America is still determined by factors (skin colour, religion, geographical location, etc.,) that make of 'difference' a valid and reliable variable for categorizing and marginalizing human beings. Strikingly, is the fact that this reaction was produced by a religious institution that is supposed to take an integral part in unifying all human beings regardless of their differences.

\section{7- Social Functions of White Americans Discourse Against Interracial Marriages}

During the analysis of the data, the researcher has stumbled upon some social functions of the discourse White Americans have developed about their attitudes against White-Black interracial marriages; such functions have been indicated to as positive self-presentation and negative other-presentation. Obviously, the talk White Americans produce against White-Black interracial marriages does not only mediate their personal views about the target issue, it does also operate to verbalize, share, and reproduce the social cognitions of the dominant group. In other words, when the participants in the TV shows articulate their attitudes against White-Black interracial communion, they do so as social members of in-group. The set of convictions, beliefs, perspectives Bardwell, Casey, and Billy hold about black people have been accounted 
on their shared societal norms, acquired values and experiences as social entities of the White race.

In discourse about Black out-group, the participants do not only disclose their shared group social cognitions, but they reveal their own experiences as well. This has been manifested in Billy's discourse. (section 6-6-1) Billy refers to his personal experience with some Black Americans to justify and explain his negative attitudes about Black Americans. These explanatory and justificatory moves serve as a self-defensive and legitimizing mechanism of his prejudiced behavioural or discursive practices.

In the same manner, legislations, commandments, and interdictions that exert power on out-groups, discourse plays a crucial role in the exercise of power and dominance. Because prejudice discourse conveys shared social cognitions, justification and explanation moves of certain negative actions, it highly likely to influence and control the cognitions and the mind of other groups.

\section{Implication}

In the light of the samples' analysis, a very significant implication is drawn out. Despite the fact that number of surveys have revealed that the rate of white-black interracial marriages has increased in America, and irrespective of the fact that all the formal restrictions on this kind of marriages have been removed out, yet in reality a number of white Americans are still reluctant to welcome this kind of communion. This truth has been realized through the very low rate white-black interracial marriage represents among other types of interracial marriages in USA, namely "less than 1\%." (Census poll)

Interracial couples are still victims of family rejection, racism, and discrimination, chiefly from the part of the majority group (the whites.) These racist attitudes white Americans form about White-Black interracial unions is "reflective of the powerful historical social boundaries between blacks and whites that continue to separate these two groups," (Yancey, 2007, pp. 197) regardless of the different justification and excuses the cases under study have used to legitimate their reactions. Yancey's argument bears a significant importance as it could be exploited to get an insight of why White-Black interracial marriage is perceived as the least favourable types of interracial communions in USA.

\section{Conclusion}

To conclude, the issue of white-black interracial marriages has been always most controversial of all types of interracial marriages in America. However, this type of 
interracial marriages have achieved advances in great strides since the 1950's, all of which reveal the fact that the American society have made a shift with regard to their perception of race issues as well as the quality of racial relations in USA. Nevertheless, it is of significant importance to mention that white-black interracial marriages are still confined to the historical social boundaries set between the whites and the blacks.

Discourse analysis of the data has shown that racism is an integral part among the White Americans. In micro-context, white Americans have represented themselves as non-racist; they have denied any racism attitudes. Rather, they outline certain motives that soften their negative attitudes against White-Black interracial communion, such as having concerns about interracial offspring rejection, that others will judge their relatives throughout their lives, that Whites' strong unity is negatively influenced by mixing with Blacks.

Furthermore, the analysis of the data reveals that some White Americans form negative attitudes about Black race only because few of them exert immoral behaviours towards members of the dominant group. All these form of racism denials have been articulated through such mechanism of mitigation, euphemistic lexical items, face-saving strategies, positive self-presentation, negative discourse about Black race.

\section{Bibliography}

[1] Blum, Lawrence. 'I'm Not a Racist, But... The Moral Quandry of Race" Cornell University Press, 2002. Print

[2] Botham, Fay. "Almighty God Created the Races: Christianity, Interracial Marriage, and American Law" The University of North- Carolina Press: 2009. Internet resource.

[3] Field, et al. "Attitudes Toward Interracial Relationships Among College Students: Race, Class, Gender, and Perceptions of Parental Views." Journal of Black Studies, Vol, 44(7), pp, 741-776, 2013. DOI: $10.1177 / 0021934713507580$

[4] Fleming, Jan. "The Dilemmas of Biracial Children." May 9, 2011. Web. 20 Jan. 2014.

[5] Grosfoguel Ramon. "What is Racism" Journal of World-Systems Research, Vol. 22 Issue 1, pp. 9-15, 2016. http://dx.doi.org/10.5195/jwsr.2016.609 | jwsr.org

[6] Hallowell, Billy. "Kentucky Church Bans Interracial Couples From Becoming Members

\&

Leading

Worship." 
http://www.theblaze.com/stories/2011/11/30/ (accessed January10. 2014).

[7] Honeycutt, et al. "Attitudes Toward Interracial Marriage and Factors Which Influence the Choice to Enter an Interracial Relationship" Sociology 30.4: 2005. https://ttu-ir.tdl.org/bitstream/handle/2346/62281/SASSERTHESIS-2015.pdf? sequence=1 (accessed February12. 2020).

[8] Jensen, Robert. "The Heart of Whiteness: Confronting Race, Racism and White Privilege" San Francisco, City Lights Publishers, 2005. Print

[9] Orbe and Harris. "Interracial Communication: theory and Practice." Sage Publications, Inc, USA, 2008

[10] Qian, Zhenchao, "Black-White Marriages Increased Rapidly Since 1980, Study Finds" http://researchnews.osu.edu/archive/intermarriage.htm (accessed 10 January. 2014).

[11] Ross, William. " The Perceptions of College Students About Interracial Relationships." NATIONAL FORUM OF APPLIED EDUCATIONAL RESEARCH JOURNALVOLUME 17, NUMBER 3, pp. 1-16, 2004. https://silo.tips/download/the-perceptions-of-college-students-aboutinterracial-relationships

[12] "Small Ky. church bans interracial couples." CBSNEWS. 30 Nov. 2011. 18 Jan. 2014. <http://www.cbsnews.com/news/small-ky-church-bans-interracialcouples/>.

[13] Sollors, Werner. "Interracialism: Black-White Intermarriage in American History, Literature, and Law.” New York: Oxford University Press, 2000. Print.

[14] Van Dijk, T. "Communicating Racisim: Ethnic Prejudice in Thought and Talk" Sage Publications Inc, California, 1987. Internet resource, www.discourses.org/OldBooks/Teun A van Dijk - Communicating Racism.pdf

[15] Van Dijk, T. "Critical Discourse Studies: a Socio-Cognitive Approach." Methods of Critical Discourse Studies, Edited by, Wodak and Meyer, Sage Publication Ltd, 2016, pp. 63-85. Print.

[16] Van Dijk, T. A. "Analyzing racism through discourse analysis: Some methodological reflections". In J. H. Stanfield II \& R. M. Dennis (Eds.), Sage focus editions, Vol. 157. Race and ethnicity in research methods, Sage Publications, Inc. p. 92-134, 1993. http://www.discourses.org/OldArticles/Analyzing\%20racism\%20through \%20discourse\%20analysis.pdf

[17] Van Dijk, Teun. 'Discourse and the Denial of Racism', Discourse \& Society 3, pp.87-118, 1992, https://doi.org/10.1177/0957926592003001005 
[18] Wang, Yujun. "A Critique of The Status Exchange Theory of Merton and Davis in Mate Assorting." Diss. Cornell University: 2006. Web. 14 Jan. 2014.

[19] Wodak and Reisigl . "Discourse and Racism: European Perspectives" Annual Review of Anthropology, Vol. 28, 1999, pp. 175-199, Published by: Annual Reviews Stable URL: http://www.jstor.org/stable/223392

[20] Yancey, George. "Experiencing Racism: Differences in the Experiences of Whites Married to Blacks and Non-Black Racial Minorities." Journal of Comparative Family Studies: 2007, Vol. 38 Issue 2

\section{Webliography}

[21] CNN. "Louisiana justice who refused interracial marriage resigns." CNN.com, November 4 , 2009 , https://edition.cnn.com/2009/US/11/03/louisiana.interracial.marriage/i ndex.html

[22] CNN News. "Justice Says Law Wasn't Broken." Youtube, Uploaded by CBS News,Oct 19, 2009, Oct 2009, https://www.youtube.com/watch?v=x7e0lQzgJbc

[23] Jones, Jenny. "Disgusted By His Sister Dating Black Men - She Should Date White Men Only!" Youtube, Interview by Jenny Jones, uploaded by Crayonscribble, Feb 22, 2014, https://www.youtube.com/watch?v=7z71nohMzE0\&t=1573s

[24] Goddard, Trisha. "Disgusted by Her Daughters Dating Black Men; I Hate Being A Black Man." Youtube, Uploaded by Magi Mego, Feb 26, 2017, https://www.youtube.com/watch?v=yCTh6JAJGyk\&t=1479s

[25] Hallowell, Billy. "Kentucky Church Bans Interracial Couples From Becoming Members \& Leading Worship." http://www.theblaze.com/stories/2011/11/30/ (Accessed January10. 2014).

[26] Johnson, Kevin, R., ed. "Mixed Race America and the Law: A Reader." New York: NYU Press, 2003. Web. 14 Jan. 2014.

[27] Jordan, Miriam. "Interracial Marriages in U.S. Reach a Record" http://www.amren.com/news/2012/02/interracial-marriages-in-u-sreach-a-record/ (accessed 10 January. 2020).

[28] Newport, Frank. "In U.S., 87\% Approve of Black-White Marriage, vs. 4\% in 1958" January http://www.gallup.com/poll/163697/approve-marriageblacks-whites.aspx. (Accessed 10 January. 2014).

[29] Powell, Colin. "Remarks at Iftaar Dinner." State.Gov, November 29, 2001, http://2001- 
2009.state.gov/secretary/former/powell/remarks/2001/6577.htm (accessed 10 January. 2014). 